\title{
The Role of Shariah Auditor in Islamic Banks: The Effect of Shariah Governance Framework (SGF) 2011
}

\author{
Mohd Rushdan Yasoa' ${ }^{1}$, Wan Amalina Wan Abdullah ${ }^{2}$ \& Wan Anisah Endut ${ }^{2}$ \\ ${ }^{1}$ Universiti Malaysia Kelantan, Malaysia \\ ${ }^{2}$ Universiti Sultan Zainal Abidin, Malaysia \\ Correspondence: Mohd Rushdan Yasoa', Universiti Malaysia Kelantan, Malaysia.
}

Received: April 10, 2020

doi:10.5430/ijfr.v11n4p443
Accepted: June 3, 2020

Online Published: July 7, 2020

URL: https://doi.org/10.5430/ijfr.v11n4p443

\begin{abstract}
This paper ascertains the current roles and responsibilities of Shariah auditor in the Islamic banking industry in Malaysia. To explore further, we identify the changes in these roles, especially after the introduction of the Shariah Governance Framework (SGF) 2011. The study employs a qualitative method by utilizing in-depth interviews with nine (9) key individuals in Malaysian Islamic banks. Our findings support the notion that Shariah auditors' roles and responsibilities are still under the jurisdiction of the banks' internal audit unit. More importantly, Shariah auditors play their roles as the third line of defense by giving assurance to the shareholders and stakeholders that all businesses and operations comply with Shariah precepts. Also, Shariah auditors need to look at the internal control elements of whether effective and efficient enough to alleviate any possible Shariah breaches. In terms of changes in its roles after the SGF implementation, most of the interviewees assert that the approach has been changed from compliance audit to risk-based audit. Our findings guide us to propose more structured and specific guidelines about Shariah auditors' roles and responsibilities in the Islamic banks. This guideline eventually could provide stimulus to improve governance and strengthen market as well as stakeholder's confidence. Finally, this study stipulates some precious recommendations to further enhance the Shariah auditor roles not only in the Malaysian Islamic banking industry but also in similar contexts.
\end{abstract}

Keywords: Shariah auditor, roles, governance, Islamic banks, Malaysia

\section{Introduction}

The impetus in internal audit research growth is associated with the increasing role of internal audit as one of the central corporate governance (CG) mechanisms (Stewart \& Subramaniam, 2010). The internal auditor's function is to assist management of the company in ensuring that a proper internal control system is in place and the business operations are conducted efficiently, effectively, and economically (Haron, Chambers, Ramsi, \& Ismail, 2004).

In the Islamic banking environment, Shariah auditor assists in developing the work of Islamic banks (Khalid, Haron, \& Masron, 2018). However, there is a relative lack of research on the role of Shariah auditors in Islamic banks. The failures of giant companies such as Enron and WorldCom lead to an emphasis on the significance of effective internal audit. Likewise, in Islamic banks, there is a need for Shariah auditors to intensify the internal control and monitoring role in the organizations. This condition entails Islamic banks leveraging internal auditing and enhancing the effectiveness of the Shariah audit, which will eventually support the organization's objective (Abdul Wahab \& Abdul Rahman, 2011). In other words, the auditor is responsible not only for the method in which the Islamic banks conduct their operations but also the effectiveness of Shariah audit operations that contribute to Shariah's principle itself (Othman \& Ameer, 2015).

The SGF 2011 outlines that the responsibility of performing the Shariah audit is at the shoulder of the internal auditor at the internal audit unit (Bank Negara Malaysia, 2011). Besides, Bank Negara Malaysia (2017) again emphasizes that the senior officer of internal audit in the Islamic banks needs to take the responsibility to oversee the Shariah audit, which is a part of the internal audit function. In other words, the internal auditors play their role not only as of the tool of corporate governance, but the function has been extended to conduct the Shariah audit in ensuring that the Islamic banks' operations are Shariah-compliant (Mohd Hanefah, Shafii, Salleh, \& Zakaria, 2014). 
On the other hand, if the Islamic banks, through its governance mechanism, fail to supervise the internal control and enhance the lines of defense in the banks, the likelihood of Shariah non-compliance (SNC) cases or events to happen is very high (Lahsasna, 2014). Consequently, the SNC cases' presence may deteriorate the reputation of Islamic banks and may weaken the confidence of customers, depositors, shareholders, and other stakeholders towards the banks (Dusuki, 2011; Shafii, Salleh, \& Shahwan, 2010).

Considering the rapid growth of the banking industry and the strict consequences for the SNC as specified in the Islamic Financial Services Act (IFSA, 2013), it is indispensable for the Islamic banks to have a proper 'check and balance' mechanism in the form of Shariah audit. This mechanism fits the objectives and the missions of its formation, the 'Maqasid as-Shariah' (Yaacob \& Donglah, 2012). Indisputably, this mechanism is essential for Islamic finance's sustainability. However, according to Yazkhiruni, Nurmazilah, \& Haslida (2018), many internal auditors and Shariah officers are still unclear about their roles and functions, whereby many of them only understand the differences in the conceptual matters, but still ambiguous in terms of its operationalization.

At present, studies specifically on Shariah auditors' roles tend to be very limited due to the nature of this area. Thus, this study will add a piece of new knowledge to the existing literature given the fact of the scarcity of the Shariah audit literature, especially concerning Shariah auditors' roles. Previous studies tend to discuss the needs for Shariah audit (Abdul Rahman, 2008), the competency of the Shariah auditor (Alam, Hassan, \& Ferdous, 2017; Mohd Ali, Mohamed, Shahimi, \& Shafii, 2015), human capital development (Shafii, Salleh, Mohd Hanefah, \& Jusoff, 2013) Shariah audit practice (Ahmad, 2017; Haji Besar et al., 2009; Hisham Kamaruddin \& Mohd Hanefah, 2017; Kasim, Mohamad Ibrahim, \& Sulaiman, 2009; Rashid, Hamid, Subhi, \& Sidek, 2017), the perceptions towards Shariah audit (Mohd Ali \& Shafii, 2014; Shafii, Ali, \& Kasim, 2014; Yaacob \& Donglah, 2012), Shariah audit model (Shafii, Zainal Abidin, \& Salleh, 2015) Shariah audit framework (Dusuki, 2011; Yussof, 2013) and Shariah audit certification (Shafii, Salleh, et al., 2014).

Besides, this study is different from past studies because many previous studies use a questionnaire survey method to gather data. According to Queirós, Faria, \& Almeida, (2017), the reliability of data from the survey is very much dependent on its structure and the accurate answers provided by their respondents. On the contrary, the current study uses a qualitative method to collect data by employing semi-structured interviews. By utilizing semi-structured questions during the interview sessions, it will open up free discussion between the researcher and participants in order to gauge as many as possible an uncover roles of Shariah auditors in Islamic banks. Therefore, this study will contribute to the existing body of knowledge in the area of Shariah audit, specifically by investigating the roles and responsibilities of Shariah auditor in the Islamic banks.

The next section will review prior literature and debate on the importance of the Shariah audit in the Islamic banking industry. Then, we describe our research methodology. In the next section, we provide some analyses into the roles and responsibilities of Shariah auditor and the changes in these roles, especially after the implementation of SGF 2011. Finally, the conclusion is drawn by emphasizing the significant issues related to this study.

\section{Literature Review}

Auditors' role in the traditional or conventional framework is limited to certification of accounts and expression of a view on the financial position of a corporation (Khan, 1985). However, undoubtedly, a regular audit has a substantial influence on the auditing role in Islamic banks (Othman \& Ameer, 2015). At the initial age of the establishment of the Islamic banking system, the Shariah auditors' roles and functions are threefold, as stipulated in the organization's articles of association (Lewis, 2006). First, the Shariah auditors advise the board as well as the company's management about the Shariah acceptability of the bank's contractual arrangements as well as new product development. Second, an independent report is provided to notify shareholders of the level of compliance with Islamic principles and to the extent that the bank is run Islamically. Third, the audit associated with the special almsgiving levy, namely zakat, must be performed to ensure that the zakat fund is being measured, managed, and allocated correctly.

The Shariah auditor must conduct the audit on the Shariah issues to comply with the Shariah rules and regulations. A survey conducted by Pricewaterhouse Cooper's in 2010 reveals that the majority of the institutions surveyed expanded the Shariah audit scope to treasury, financing, operations, credit administration, disbursements, recovery, legal and process of Shariah fatwa. However, only half of the respondents had expanded the Shariah audit scope to Human Resources and Risk Management (PwC, 2011).

Another view proposes a similar opinion that the Shariah auditor should perform the audit on the central issues in Islamic banks' financial statements. This audit could be achieved by attesting the financing (debt or equity), 
investment, risk management, and hedging tools, income and expenses recognition, and distribution of profit as well as the computation and payment for zakat (Mohd Hanefah et al., 2014). Moreover, the business activities of Islamic banks must be audited to ensure that the events can benefit the public, investors, depositors, and shareholders of the Islamic banks. This audit is also to ensure that they do not bring harm to the public (Lahsasna, Hameed, \& Alhabshi, 2012; Yussof, 2013).

In supporting this argument, Yahya \& Mahzan (2012) contend that Shariah auditors' role in the Islamic economy is entirely different as they are accountable to the public at large and uphold Islamic principles. The Shariah auditor does not only have to conduct an audit on financial statements but also compliance audits of the organizational structure, people and processes as well as audit review of the sufficiency of the Shariah governance process. Finally, they should also provide recommendations to the Board Audit Committee (BAC) and the Shariah Committee (ShC) (Othman \& Ameer, 2015).

Shariah auditor duties range from an examination of many types of contracts, product structures, reporting of transactions, financial statements, marketing information, and any other legal forms and documents relevant to Islamic banking operations (Othman \& Ameer, 2015). However, considering that many new developments in rules and regulations, inherent risks, as well as types of products and services issued by Islamic banking operations, it is deemed vital to ascertain the current roles and responsibilities of Shariah auditor in the Islamic banking industry as well as the changes in these roles after the implementation of SGF2011.

\section{Methodology}

This study's main objective is to ascertain the current role of Shariah auditors in Islamic banks based on practitioners' views and experiences. To achieve this objective, a few in-depth interview series have been conducted. Even though about 32 institutions are offering Islamic banking products and services, only 9 of them agree to participate.

There are four groups involved in this study, namely full-fledged Islamic banks (FFIB), Islamic banking subsidiaries (IBS), development financial institutions (DFI), and Islamic window (IW). FFIB refers to either local or international banks that only offer Islamic banking products or services. Their operation is ruled by the IFSA 2013. Besides, IBS is a conventional bank with an Islamic banking subsidiary whereby it is governed by the IFSA 2013 and the Financial Services Act 2013 (FSA 2013). Meanwhile, DFIs refer to specialized financial institutions established by the government of Malaysia to develop and stimulate important sectors to achieve the country's socio-economics' objectives by offering Islamic products and services. DFIs have been categorized under the jurisdiction of the Development Financial Institutions Act 2002 and IFSA 2013 for their Islamic banking business operation. Lastly, IW is a commercial bank given a license by Bank Negara Malaysia to offer Islamic banking products and services. Like IBS, IW's activity is also administrated by the IFSA 2013 and FSA 2013 in their business operation (Bank Negara Malaysia, 2018).

In this study, the selection of respondents is based on purposive sampling. Even though the sample size of respondents is relatively small, but it is considered normal in a qualitative study because they are selected based on the criteria that they would provide useful information on the phenomenon under investigation. (Creswell \& Poth, 2018). The mix of the Shariah auditors and the Head of Shariah auditors provides fruitful details on the role of Shariah auditors in performing the Shariah audit effectively (Mohd Ali, Mohamed, Shahimi, \& Shafii, 2015). On top of that, perceptions from the other relevant participants other than Shariah auditors, such as from Chief Shariah officer and ShC member, are also pertinent in validating the role of Shariah auditors to produce robust and unbias result.

Before the analysis can be performed, the verbatim transcription was accomplished for all interview sessions by employing the Computer Assisted Qualitative Design Analysis Software (CAQDAS), namely Atlas.ti version 8.0. This software is used to facilitate the process of transcribing the interview and data coding. The respondents were coded based on the types of group and position so that it would keep the confidentiality of the data. For instance, HSA-FFIB will be referring to the Head of Shariah Audit from full-fledged Islamic Bank without specifically mention the institution's name. Finally, the study comes out with the list of interviewees for the study, as presented in Table 1 below: 
Table 1. Interviewees for the study

\begin{tabular}{|c|c|c|c|}
\hline Types of Group & Position & $\begin{array}{l}\text { Respondent } \\
\text { Code }\end{array}$ & Total \\
\hline \multirow{3}{*}{$\begin{array}{l}\text { Full-fledged Islamic } \\
\text { Banks (FFIB) }\end{array}$} & Chief Shariah Officer & CSO-FFIB & 1 \\
\hline & Head of Shariah Audit & HSA-FFIB & 1 \\
\hline & Head Office and Shariah Audit & HOSA-FFIB & 1 \\
\hline \multirow{2}{*}{$\begin{array}{l}\text { Islamic Banking } \\
\text { Subsidiaries (IBS) }\end{array}$} & Head of Islamic Banking Audit & HIBA-IBS & 1 \\
\hline & $\begin{array}{l}\text { Senior Director of Islamic Business } \\
\text { Unit }\end{array}$ & SDIBU-IBS & 1 \\
\hline \multirow{3}{*}{$\begin{array}{l}\text { Development Financial } \\
\text { Institutions (DFI) }\end{array}$} & Head of Shariah Audit & HSA-DFI & 1 \\
\hline & Shariah Auditor & SA-DFI & 1 \\
\hline & Shariah Committee Member & ShC-DFI & 1 \\
\hline Islamic Windows (IW) & Head of Shariah Audit & HSA-IW & 1 \\
\hline Total & & & 9 \\
\hline
\end{tabular}

\section{Findings and Discussion}

\subsection{The Current Role of Shariah Auditor}

The interviews have provided a lot of information on Shariah auditor's role in the Islamic banks. As proposed by the SGF, all the Shariah audit sections or units are located under the Internal Audit Department (IAD) of the Islamic banks. Regarding the Shariah auditor role, respondents from the four (4) groups of interviewees provide mixed views on the matter accordingly. The majority of them agreed that Shariah auditor should provide objective assurance that the Islamic banks comply with the Shariah precepts. As one of the respondents explains:

"...The current role of Shariah auditor is to give assurance to the audit committee of the board plus full board, regulators, as well as our stakeholders and our customers that all the businesses comply with Shariah..." (SDIBU-IBS).

"...As Shariah auditors, we play our roles to ensure assurance in terms of Shariah audit as the third line of defense and to ensure the works of the second line and first-line..." (HOSA-FFIB).

Shafii, Salleh, Mohd Hanefah \& Jusoff, (2013) support these views by citing that the internal auditor does not only act as a player to ensure corporate governance and providing internal consultancy (Stewart \& Subramaniam, 2010). Other than that, the roles have also been expanded to perform Shariah audit in ensuring that the operations of the Islamic financial institutions (IFIs) are Shariah-compliant.

However, one of the respondents from FFIB highlights that Shariah auditor should not only focus on the assurance by validating the transactions alone but, more importantly, is to perform the effective control element to alleviate SNCs (Yaacob \& Donglah, 2012). As one of the respondents remarks:

"...The role of Shariah auditors is to provide independent assurance as the third level of defense to Islamic banking operations, and they do not only look at the validity of transactions but also look at the internal control element of whether effective and efficient enough to mitigate any possible Shariah breaches..." (CSO-FFIB).

Nevertheless, one of the respondents, also a ShC member of DFI, claims that Shariah auditor should only focus on their roles on the Shariah audit and cannot mingle with the other functions. This approach is basically to ensure that they will be able to uncover many issues, especially on Shariah. Her argument indisputably has a basis and delivers as follows:

"... When Shariah auditors conduct the Shariah audit, they cannot audit the other things, but they should only focus on Shariah compliance. If they do that, then, maybe they will be able to detect so many issues and findings in the organizations..." (ShC-DFI).

In line with this argument, Roussy \& Brivot (2016) contend that to produce quality work, internal auditors should avoid consultancy assignments for top management and focus on assurance assignments only (in this case, Shariah audit). The other respondent supports this argument by asserting that when the Shariah auditors in the organization can play their function effectively, then the role of the other Shariah organs in the Islamic banks is not critical in the next accounting period. He remarks as: 
"...If Shariah audit has been able to play an effective role, then the existence of Shariah review is not overly critical..." (CSO-FFIB).

Indeed, the existence of the Shariah audit roles is very significant to consult ShC, especially about the business operations because they (Shariah auditors) are well versed with the processes, products, people, and systems in the organization. One of the respondents stresses out the point as below:

"...Internal Shariah audit role is to advise the ShC on the operations to give a clear and better understanding of the operations, what is happening with regards to the whole process from A to Z because that is the bread and butter of audit. The ShC only focuses on Shariah ruling, Shariah concept, and Shariah structure. Still, in terms of applicability, maybe they don't have the skills because they do not involve in the operation..." (HIBA-IBS).

On the other hand, with the existence of the Shariah audit role, it is undoubtedly required for the Shariah Committee members to comprehend the procedures, process, and system in the bank (Shafii, Abidin, Salleh, Jusoff, \& Kasim, 2013).

On the importance of having an audit background, one of the respondents argues that the Shariah auditor must have an audit background. This condition is due to the aspiration that the Shariah auditor might be able to play their roles and duties effectively, and comprehensively shall they have a proper audit background. As the respondent contends:

"...Number one is we (Shariah auditor) should have an audit background, then followed by Shariah. If Shariah auditor has Shariah background only and no internal audit, then that Shariah auditor has no prejudice thinking in performing their role..." (HOSA-FFIB).

Even though most of the scholars (Haji Besar, Abd Sukor, Abdul Muthalib, \& Gunawa, 2009; Khalid et al., 2018; Muneeza \& Hassan, 2014; Zaid, 2010) highlight that auditors need to perform their judgment without bias or prejudice, HOSA-FFIB provides new insight that the Shariah auditor must have a 'prejudice' thinking by having an audit background. This is because by having this 'prejudice' thinking, it is anticipated that they will be able to critically investigate issues, especially those of SNC cases, and perform their job effectively.

Conclusively, it is agreed from the interviews that the Shariah auditor's roles and responsibilities shall be as follows:

i. To assure the shareholders and stakeholders that all the businesses and operations comply with Shariah,

ii. to serve as the third line of defense,

iii. to look into the internal control element of whether effective and efficient enough to prevent any possible Shariah breaches,

iv. to emphasize on Shariah compliances to detect many issues, and

v. to advise the ShC on the operations by giving a clear and better understanding of the activities.

4.2 The Changes in the Role After the Issuance of SGF 2011

There are mixed views presented by respondents in terms of changes in the role of Shariah auditor, especially after the issuance of SGF 2011. Even though the majority of the respondents express that there is a change in terms of Shariah auditor's role. Still, few of them assert that there are no significant changes since the implementation of SGF 2011. In this respect, one of the respondents says that Shariah auditor's role is not much different, as Shariah auditor's most critical concern is the SNC issue. This certainly differentiates Shariah auditor from the conventional auditor as he states:

"... Before 2011, there is no guideline what so ever. So, from there until now, basically in terms of our roles when we talk about Shariah audit per se, actually there is not much any change because our scope as far as Shariah audit is concerned only one which is SNC..." (HIBA-IBS).

Even though in general, one of the respondents from full-fledged Islamic bank supports his view by stating that there is no change in terms of Shariah auditor's role, but they need to change their worldview from operation-wise to Shariah-wise, and they need to consider the risk-based approach. The audit approach based on the risk is also in line with the suggestion made by most of the previous scholars (Caratas \& Spatariu, 2014; Chambers \& Odar, 2015; Danescu, Prozan, \& Prozan, 2015; Dittenhofer, 2001; Hassan, 2012) as well as guidelines (AAOIFI, 2017; The Institute of Internal Auditors (IIA), 2012). Some of their opinions are as follows:

"...There is no change. We only need to change the head (thought) in terms of operation-wise to Shariah. In terms of audit, the responsibility is getting bigger, but the expectation in term of quality control and governance, it remains as audit work. But now in terms of role in advisory applied and risk-based is to consider for the enhancement. 
Previously it is compliance-based, and now it is risk-based. Previously we are 'orthodox' because we searched for finding. But, now we are advisors and consultants to our auditees, that's it..." (HOSA-FFIB).

"...In terms of changes, whenever there are any new emerging risks, we need to reassess our risk assessment approach. So, in terms of changes since 2011, I did not see any changes unless BNM issues a new requirement. As of now, we just follow the existing requirement, as stated in SGF..." (HSA-FFIB).

In a similar vein, a chief Shariah officer from full-fledged Islamic banks explains why the changes of approach are required even though the fundamental roles and responsibilities of Shariah auditors remain under the jurisdiction of internal audit job scope. He highlights that:

"...From the viewpoint of Shariah auditor's role in this bank, nothing has changed from the actual reporting line since the beginning. However, there is a slight change after SGF implementation whereby the internal audit process has been changed from a compliance audit to a risk-based audit by utilizing a risk-based approach. This is because the overall auditing approached employed by the bank is starting to adopt the COSO framework. So, the Shariah audit uses a risk-based approach, which is based on the IIA framework. Since then, the role of a compliance audit is now being taken over by Shariah review..." (CSO-FFIB).

From the other side of the coin, the respondents claim that changes in the Shariah auditor's role have their arguments and justifications. One of the respondents dispute that:

"...I think it becomes stricter or more thorough when it comes to the Shariah audit. Before SGF, there are none of the Shariah audits. Still, after that, we can see that Shariah audit is developing, and institutions also start having more structures and processes to do Shariah audit. ..." (ShC-DFI)

One of Shariah auditor from DFI also expresses a similar sentiment that the roles of Shariah auditor are much broader as compared to the previous year as she highlights:

"...The roles and responsibilities of Shariah auditors are much broader than those previous years concerning product structures, transaction reporting, preparation of financial statements, reports, marketing circular, and any other legal documents. The roles and responsibilities of Shariah Auditor expanded from pre-event to post-event rather than pure post-event detection of non-compliance to Shariah requirements..." (SA-DFI).

Her statement confirms that the Shariah audit roles are not only for post-event detection but also cover pre-event detection. Indeed, this finding extends the finding by Othman \& Ameer (2015) that claim the Shariah audit function is aimed at auditing that there is adherence to Shariah compliance after a product has been issued only. Since product development process consists both pre-product approval (i.e., product structuring before releasing to the market) and post-product authorization (i.e., a process after the product has been released to the market) (Bank Negara Malaysia, 2011), therefore, our study suggests that a significant role of Shariah auditor should cover as early as pre-event to post-event detection.

On top of that, a senior director of the Islamic business unit from Islamic banking subsidiaries further explains Shariah auditor's responsibility to submit the report to ShC. In this juncture, she remarks that:

"...We can see the Shariah audit function's role is to assist ShC in ensuring everything is in place. Previously, we do not report to ShC. Instead, all the audit reports were submitted to BAC (Board Audit Committee), and we will stop there. But, after the introduction of SGF, we extent the report to ShC..." (SDIBU-IBS).

Besides, SDIBU-IBS continues to explain that after SGF2011, unlike conventional or regular auditor, Shariah auditor should consider two (2) perspectives, namely control, and Shariah perspectives as she contends:

"...I think before SGF, it (Shariah audit) was not mandated. The function is just more or less. The auditors just cover the business operation from a control perspective. After the issuance of SGF, the function is more dedicated in the sense that it is more defined, and it is more conclusive to cover the Shariah aspect as well. In other words, we can define those two things, control as well as Shariah requirement..." (SDIBU-IBS).

Shafii, Abidin, et al. (2013) support this view by asserting that Shariah auditor proposes a proper internal control system to the ShC in mitigating any SNC in the banks from recurring in the future. Before SGF, most of the products have been approved as it is, and there are no proper precautionary methods suggested to ShC.

Another change is underlined by CSO-FFIB, whereby he contends that there is a change in terms of Shariah auditors' perspectives and roles. According to him, Shariah auditors gradually have changed their role from a faultfinder to become an advisor or consultant for the business unit. This is actually in line with the prior findings, as suggested by 
most of the scholars (Lenz \& Hahn, 2015; Mat Yasin \& Nelson, 2012; Munteanu \& Laurentiu, 2014; Stewart \& Subramaniam, 2010; Yussof, 2013). About this view, he remarks that:

"...Even now, our audit has not only played a role in identifying weaknesses, but we have moved into the advisory and consultancy role. So, the internal audit is the consultant to the business unit and the support unit. The relationship is established not only during the audit visit but also outside the audit visit, which is in line with the development of the internal audit in the market and industry..." (CSO-FFIB).

In a nutshell, the findings discovered that the roles played by the Shariah auditor is of essential, and it is fundamentally a mechanism that should be efficiently and effectively used by the Islamic banks. Even though there are mix opinions on the changes in the roles and responsibilities of Shariah auditors after the implementation of SGF2011, it can be concluded that:

i. Shariah auditor should focus on SNC by giving greater emphasis on Shariah issues;

ii. the approach has been changed from a compliance audit to risk-based audit;

iii. the roles of Shariah auditor are much broader and cover all aspects of businesses and operations ranging from pre-event to post-event detection of SNC;

iv. Shariah auditor should submit the audit findings and report to BAC as well as ShC;

v. Shariah auditor needs to consider two perspectives, internal control, and Shariah requirement; and

vi. views and roles of Shariah auditors have changed from a fault finder to become advisors or consultants to auditees.

\section{Conclusion}

This paper attempts to identify the roles and responsibilities of Shariah auditor in Islamic banks, and it changes, especially after the implementation of SGF2011. Our findings confirm that the roles and responsibilities of Shariah auditors fall under the jurisdictions of the internal audit unit of the banks. Shariah auditors play their roles as the third line of defense by giving assurance to the shareholders and stakeholders that all the businesses and operations comply with Shariah precepts. Besides, Shariah auditors need to look at the internal control elements of whether effective and efficient enough to prevent any possible Shariah breaches. In terms of changes in its roles, especially after the implementation of SGF 2011, most of the interviewees claim that the approach has been changed from compliance audit to risk-based audit. They also changed their perspectives from a faultfinder to become an advisor or a consultant for auditees. However, due to loose guidelines provided by the Bank Negara Malaysia through SGF2011, especially in Shariah audit roles, most of the interviewees are still waiting for the new Shariah Governance that is promised to be released soon possible. Our findings guide us to propose more structured and specific guidelines of the roles and responsibilities of Shariah auditors in Islamic banks, which could provide stimulus to improve corporate governance and strengthen market as well as stakeholder's confidence.

The results offered in this study have particular implications for other Islamic jurisdictions around the globe that have a similar setting as Malaysia. Understanding the current roles of Shariah auditors in the Islamic banking industry is crucial to enhance the Shariah governance system as well as Shariah compliance in the Islamic banks. Thus, this study provides a significant contribution to the implementation of the Shariah audit in Islamic banks. Also, even though there are limited numbers of respondents through interviews, this study manages to explore and elaborate issues in understanding the role of Shariah auditor. It also apprehends thoughts and intentions that are difficult to be observed using other methods (Creswell \& Poth, 2018).

Like other empirical researches, this study also has its limitations. First, not all the essential key persons in Islamic banks were eager to share their valuable experience with us due to time constraints. Second, interviewees consist of only nine (9) members, namely Shariah auditors, Heads of Shariah audit, Shariah Committee member, and the chief Shariah officer. The small interviewees' size can disputably limit the depth of discussions on the relevant issues. Future research could be conducted to capture more data from other experts like regulators and external auditors.

\section{Acknowledgments}

Authors would like to acknowledge all supports from Faculty of Business and Management as well as Center for Research Excellence \& Incubation Management, Universiti Sultan Zainal Abidin, Terengganu, Malaysia.

\section{References}

AAOIFI. (2017). Exposure draft of the auditing standard for Islamic financial institutions No. 6: External Shariah audit (independent assurance engagement on an Islamic financial institution's compliance with Shari'ah 
principles and rules), Pub. L. No. 6, 1.

Abdul Rahman, A. R. (2008). Shariah audit for Islamic financial services: The needs and challenges. In ISRA Islamic Finance Seminar (IIFS) (pp. 1-14). Kuala Lumpur.

Abdul Wahab, N., \& Abdul Rahman, A. R. (2011). A framework to analyse the efficiency and governance of zakat institutions. Journal of Islamic Accounting and Business Research, 2(1), 43-62. https://doi.org/10.1108/17590811111129508.

Ahmad, S. (2017). Practice of Shariah Audit in Islamic Banking in Pakistan. Journal of Islamic Economics, Banking and Finance, 13(2), 102-127.

Alam, T., Hassan, T., \& Ferdous, K. (2017). Competency of Shariah auditors: Issues and challenges in Pakistan. Journal of Internet Banking and Commerce, 22(2), 1-12. https://doi.org/10.12816/0024798.

Bank Negara Malaysia. (2011). Shariah governance framework for Islamic financial institutions. Malaysia. https://doi.org/10.1007/s13398-014-0173-7.2

Bank Negara Malaysia. (2017). Shari'ah Governance Exposure Draft. Malaysia.

Bank Negara Malaysia. Operational Risk Integrated Online Network (ORION) - Policy Document (2018). Retrieved from http://www.bnm.gov.my/index.php?ch=57\&pg=543\&ac=740\&bb=file

Caratas, M. A., \& Spatariu, E. C. (2014). Contemporary approaches in internal audit. Procedia Economics and Finance, 15(14), 530-537. https://doi.org/10.1016/S2212-5671(14)00503-6

Chambers, A. D., \& Odar, M. (2015). A new vision for internal audit. Managerial Auditing Journal, 30(1), 34-55. https://doi.org/10.1108/MAJ-08-2014-1073

Creswell, J. W., \& Poth, C. N. (2018). Qualitative Inquiry and research design choosing among five approaches (Fourth Edi). Thousand Oaks, Calif.: SAGE Publications Inc. https://doi.org/10.2307/1523157

Danescu, T., Prozan, M., \& Prozan, R. D. (2015). The valances of the internal audit in relationship with the internal control - corporate governance. Procedia Economics and Finance, 26(15), 960-966. https://doi.org/10.1016/S2212-5671(15)00915-6

Dittenhofer, M. (2001). Internal auditing effectiveness: an expansion of present methods. Managerial Auditing Journal, 16(8), 443-450. https://doi.org/10.1108/EUM0000000006064

Dusuki, A. W. (2011). Introduction to Shariah audit framework. In International Shariah Audit Conference 2011. Kuala Lumpur: International Shariah Research Academy for Islamic Finance.

Haji Besar, M. H. A., Abd Sukor, M. E., Abdul Muthalib, N., \& Gunawa, A. Y. (2009). The practice of Shariah review as undertaken by Islamic banking sector in Malaysia. International Review of Business Research Papers, 5(1), 294-306.

Haron, H., Chambers, A., Ramsi, R., \& Ismail, I. (2004). The reliance of external auditors on internal auditors. Managerial Auditing Journal, 19(9), 1148-1159. https://doi.org/10.1108/02686900410562795

Hassan, J. al-S. (2012). The impact of global financial crisis on auditing practices in the commercial banks of Jordanian. British Journal of Economics, Finance and Management Sciences, 6(2), 108-115.

Hisham Kamaruddin, M. I., \& Mohd Hanefah, M. (2017). Enhancing Shariah audit practices in Islamic financial institutions in Malaysia. Journal of Modern Accounting and Auditing, 13(11), 457-470. https://doi.org/10.17265/1548-6583/2017.11.001

IFSA. Islamic Financial Services Act 2013. (2013). Malaysia.

Kasim, N., Hameed, Mohamad Ibrahim, S. H., \& Sulaiman, M. (2009). Shariah Auditing in Islamic Financial Institutions: Exploring the Gap between the "Desired" and the "Actual." Global Economy and Finance Journal, 2(2), 127-137.

Khalid, A. A., Haron, H., \& Masron, T. A. (2018). Competency and effectiveness of internal Shariah audit in Islamic financial institutions. Journal of Islamic Accounting and Business Research, 9(2), 201-221. https://doi.org/10.1108/JIABR-01-2016-0009

Khan, M. A. (1985). Role of the auditor in an Islamic economy. Journal of Research in Islamic Economics, 3(1), $31-41$.

Lahsasna, A. (2014). Shariah non-compliance risk management and legal documentation in Islamic finance. 
Singapore: John Wiley \& Sons Singapore Pte. Ltd.

Lahsasna, A., Hameed, S. M. I., \& Alhabshi, S. O. (2012). Shariah audit: Evidence \& methodology in Islamic finance. Kuala Lumpur.

Lenz, R., \& Hahn, U. (2015). A synthesis of empirical internal audit effectiveness literature pointing to new research opportunities. Managerial Auditing Journal, 30(1), 5-33. https://doi.org/10.1108/MAJ-08-2014-1072

Lewis, M. (2006). Accountability and Islam. In Fourth International Conference on Accounting and Finance in Transition (pp. 1-16). Adelaide.

Mat Yasin, F., \& Nelson, S. P. (2012). Audit committee and internal audit: implications on audit quality. International Journal of Economics, Management and Accounting, 20(2), 187-218.

Mohd Ali, N. A., Mohamed, Z. M., Shahimi, S., \& Shafii, Z. (2015). Competency of Shariah auditors in Malaysia: issues and challenges. Journal of Islamic Finance, 4(1), 22-30. https://doi.org/10.12816/0024798

Mohd Ali, N. A., \& Shafii, Z. (2014). The Undergraduates' Perspective on Shariah Audit in Islamic Banks: An Insight to the Future Shariah Auditor Labour Market in Malaysia. Gading Business and Management Journal, $18(1), 1-20$.

Mohd Hanefah, M., Shafii, Z., Salleh, S., \& Zakaria, N. (2014). Governance and Shariah audit in Islamic financial institutions (2nd ed.). Nilai, Negeri Sembilan: Penerbit Universiti Sains Islam Malaysia.

Muneeza, A., \& Hassan, R. (2014). Shari'ah corporate governance: the need for a special governance code. Corporate Governance: The International Journal of Business in Society, 14(1), 120-129. https://doi.org/10.1108/CG-02-2011-0015

Munteanu, V., \& Laurentiu, D. (2014). Current trends in internal audit. Procedia - Social and Behavioral Sciences, 116, 2239-2242. https://doi.org/10.1016/j.sbspro.2014.01.551

Othman, R., \& Ameer, R. (2015). Conceptualizing the duties and roles of auditors in Islamic financial institutions. Humanomics, 31(2), 201-213. https://doi.org/10.1108/H-04-2013-0027

PwC. (2011, December). Shariah Audit: Industry Insights. PricewaterhouseCoopers Malaysia, 1-28.

Queirós, A., Faria, D., \& Almeida, F. (2017). Strengths and limitations of qualitative and quantitative research methods. European Journal of Education Studies, 3(9), 369-387. https://doi.org/10.5281/zenodo.887089

Rashid, A. A., Abdul Hamid, M., Mohamad Sidek, A. S., Wan Abdullah, W. M. T., \& Mohd Ali, I. (2017). Shari'ah auditing: A review of shari'ah audit practices in Islamic financial institution (IFIs). SHS Web of Conferences 36, $00019,1-5$.

Roussy, M., \& Brivot, M. (2016). Internal audit quality: a polysemous notion?. Accounting, Auditing and Accountability Journal, 29(5), 714-738. https://doi.org/10.1108/AAAJ-10-2014-1843

Shafii, Z., Abidin, A. Z., Salleh, S., Jusoff, K., \& Kasim, N. (2013). Post implementation of Shariah governance framework: The impact of Shariah audit function towards the role of Shariah committee. Middle-East Journal of Scientific Research (Research in Contemporary Islamic Finance and Wealth Management):, 13, 7-11. https://doi.org/10.5829/idosi.mejsr.2013.13.1874

Shafii, Z., Ali, N. A. M., \& Kasim, N. (2014). Shariah Audit in Islamic Banks: An Insight to the Future Shariah Auditor Labour Market in Malaysia. Procedia - Social and Behavioral Sciences, 145(1), 158-172. https://doi.org/10.1016/j.sbspro.2014.06.023

Shafii, Z., Salleh, S., Mohd Hanefah, H. M., \& Jusoff, K. (2013). Human capital development in Shariah audit. Middle-East J. Sci Res (Research in Contemporary Islamic Finance and Wealth Management), 13(6), 28-34. https://doi.org/10.5829/idosi.mejsr.2013.13.1878

Shafii, Z., Salleh, S., \& Shahwan, S. (2010). Management of Shariah non-compliance audit risk in the Islamic financial institutions via the development of Shariah compliance audit framework and Shariah audit programme. In Kyoto Bulletin of Islamic Area Studies (pp. 3-16).

Shafii, Z., Zainal Abidin, A., \& Salleh, S. (2015). Integrated Internal-External Shariah Audit Model : A Proposal towards the Enhancement of Shariah Assurance Practices in Islamic Financial Institutions (WP\#1436-07). Jeddah. https://doi.org/RePEc:ris:irtiwp:1436_007

Stewart, J., \& Subramaniam, N. (2010). Internal audit independence and objectivity: emerging research opportunities. 
Managerial Auditing Journal, 25(4), 328-360. https://doi.org/10.1108/02686901011034162

The Institute of Internal Auditors (IIA). International standards for the professional practice of internal auditing (2012). USA.

Yaacob, H., \& Donglah, N. K. (2012). Shariah audit in Islamic financial institutions: The postgraduates' perspective. International Journal of Economics and Finance, 4(12), 224-239. https://doi.org/10.5539/ijef.v4n12p224

Yahya, Y., \& Mahzan, N. (2012). The role of internal auditing in ensuring governance in Islamic financial institution (IFI). In 3rd International Conference on Business and Economic Research (pp. 2158-2162). Bandung, Indonesia.

Yazkhiruni, Y., Nurmazilah, M., \& Haslida, A. H. (2018). A review of Shariah auditing practices in ensuring governance in Islamic financial institution (IFIs)-A preliminary study. Advances in Social Sciences Research Journal, 5(7), 196-210. https://doi.org/10.14738/assrj.57.4873

Yussof, S. A. (2013). Prospects of Shariah audit framework for Islamic financial institutions in Malaysia. Islam and Civilisational Renewal, 4(3), 80-102. https://doi.org/10.12816/0009724

Zaid, O. A. (2010). The appointment qualifications of Muslim accountants in the middle ages. Accounting Education, 9(4), 329-342. https://doi.org/10.1080/0963928001001264. 